ORIGINAL ARTICLE

\title{
Interaction of Desulfovibrio desulfuricans biofilms with stainless steel surface and its impact on bacterial metabolism
}

\author{
F.A. Lopes ${ }^{1}$, P. Morin ${ }^{1}$, R. Oliveira ${ }^{1}$ and L.F. Melo ${ }^{2}$ \\ 1 Centro de Engenharia Biológica, Universidade do Minho, Braga, Portugal \\ 2 Faculdade de Engenharia do Porto, Departamento de Engenharia Química, Universidade do Porto, Porto, Portugal
}

\section{Keywords}

alloying elements, biocorrosion, nickel, passive

film, sulfate-reducing bacteria, stainless steel.

\section{Correspondence}

F.A. Lopes, Service de la corrosion et du comportement des matériaux dans leur environnement, Commissariat à l'Energie Atomique - CEA/Saclay, bâtiment 458, 91191 Gif-sur-Yvette Cedex, France. E-mail: fil.lopes@free.fr; falopes@deb.uminho.pt

2004/0655: received 8 June 2004, revised and accepted 2 March 2006

doi:10.1111/j.1365-2672.2006.03001.x

\begin{abstract}
Aims: To study the influence of some metallic elements of stainless steel 304 (SS 304) on the development and activity of a sulfate-reducing bacterial biofilm, using as comparison a reference nonmetallic material polymethylmethacrylate (PMMA).

Methods and Results: Desulfovibrio desulfuricans biofilms were developed on SS 304 and on a reference nonmetallic material, PMMA, in a flow cell system. Steady-state biofilms were metabolically more active on SS 304 than on PMMA. Activity tests with bacteria from both biofilms at steady state also showed that the doubling time was lower for bacteria from SS 304 biofilms. The influence of chromium and nickel, elements of SS 304 composition, was also tested on a cellular suspension of Des. desulfuricans. Nickel decreased the bacterial doubling time, while chromium had no significant effect.

Conclusions: The following mechanism is hypothesized: a Des. desulfuricans biofilm grown on a SS 304 surface in anaerobic conditions leads to the weakening of the metal passive layer and to the dissolution in the bulk phase of nickel ions that have a positive influence on the sulfate-reducing bacteria metabolism. This phenomenon may enhance the biocorrosion process.

Significance and Impact of the Study: A better understanding of the interactions between metallic surfaces such as stainless steel and bacteria commonly implied in the corrosion phenomena which is primordial to fight biocorrosion.
\end{abstract}

\section{Introduction}

Biofilms grown on any surface in contact with aqueous environment produce an environment that is radically different from the bulk medium in terms of $\mathrm{pH}$, dissolved oxygen, organic and inorganic species (Wagner and Little 1993). Microbes in a biofilm may provoke or accelerate corrosion in several ways, e.g. by formation of concentration and differential aeration cells, by directly oxidizing/ reducing metallic atoms/ions and by producing corrosive metabolic by-products that act on the destruction of the passivating films (Little et al. 1992; Videla 2001).

Stainless steel is used in numerous applications as diverse as nuclear power plants, service water systems and oil drilling platforms (Biezma 1999; Javaherdashti 1999).
One of the main types of bacteria associated with corrosion failures of cast iron, mild steel and stainless steel structures in both aquatic and terrestrial environments, under anoxic and oxygenated conditions, is the sulfatereducing bacteria (SRB) (Feugeas et al. 1997; Geesey et al. 2000). SRB belong to a mixed group of morphologically and nutritionally diverse, anaerobic bacteria, which utilize sulfate (or other oxidized sulfur compounds) as an electron acceptor for the dissimilation of organic compounds and produce sulfide (Gibson 1990). The activities of SRB in natural and artificial systems are of great concern to many different industrial operations. In particular, oil, gas and shipping industries are seriously affected by these bacteria (Odom 1990; Geesey et al. 2000). 
Corrosion of mild steel because of SRB has been the subject of numerous studies and the possible mechanisms involved in such interaction have been frequently described in the literature (Lee et al. 1995; Beech and Gaylarde 1999; Geesey et al. 2000; Hamilton 2003; Dinh et al. 2004).

Stainless steel owes their corrosion resistance to the inclusion of alloying elements such as chromium (Cr), nickel $(\mathrm{Ni})$, manganese $(\mathrm{Mn})$ and possibly molybdenum (Mo) in their metallurgical formulation. The mechanism of corrosion resistance of the steel results from the reaction of the mentioned alloying elements with oxygen to establish a stable oxide film that passivates the surface of steel (Uhlig 1975a; Hamilton 1999).

In spite of their good passive behaviour, stainless steel is sensitive to corrosion, such as the intergranular and pitting corrosion (Uhlig 1975b; Feugeas et al. 1997). Sulfides enhance the susceptibility of stainless steel to corrosion in several ways, i.e. by promoting the active dissolution, delaying repassivation and by rendering the passive film less protective (Biezma 1999; Rao and Satpathy 1999). Chen and Clayton (1997) demonstrated the formation of sulfides and thermodynamically unstable products during exposure of stainless steel 304 (SS 304) to Desulfovibrio desulfuricans causing loss of the steel passivity. Beech et al. (1998) also demonstrated that the profile of the chemical elements within the passive layer of stainless steel 316 (SS 316) and its thickness markedly changed by exposing this surface to Pseudomonas sp. compared with the unexposed steel.

The alloying elements of stainless steel, such as chromium, nickel and molybdenum added to steel in order to improve their performance, particularly the corrosion resistance, may be dissolved during the corrosion process and influence bacterial adhesion and further biofilm development. Differences in bacterial settlement between SS 304 and SS 316 may be related to the presence of molybdenum in the passive film that would be exposed to biofilm-forming bacteria if this oxide layer is damaged (Edyvean et al. 1996). Chen et al. (1998) demonstrated that the exposure of Des. desulfuricans to sputter-deposited molybdenum thin films led to Mo dissolution, subsequently delaying the culture growth and the rate of sulfate reduction. According to these authors, the dissolution of Mo may be induced by the produced hydrogen sulfide and further increased by the intermediate sulfurcontaining amino groups and proteins. These authors pointed out the importance of the interaction between SRB cells and molybdenum-containing surfaces, indicating that SRB are frequently involved in the corrosion of Mo-bearing steel, such as SS 316. It should be noted that usually the research works on corrosion of metallic surfaces because of SRB activity only evaluate the influence of these bacteria on the deterioration of the metal, meaning that they only discuss the interaction in one way ( $\mathrm{SRB} \Rightarrow$ metal). Therefore, it may be worth examining the interaction SRB/metal in the opposite direction ( $\mathrm{SRB} \Leftarrow$ metal) in order to understand the influence of metallic elements of the surface on bacterial metabolism and biofilm development.

This study has been undertaken to compare the development and activity of a sulfate-reducing biofilm formed on SS 304 and on polymethylmethacrylate (PMMA) surfaces. PMMA was chosen as a reference (blank) surface because this material has no metallic element in its composition. In addition, as stainless steel surfaces have been recognized to suffer from MIC because of SRB activity, it was thought appropriate to study the effect of the main alloying elements present in the composition of the steel, chromium and nickel, on the growth of Des. desulfuricans cell suspensions.

\section{Materials and methods}

\section{Bacterial inoculum}

The sulfate-reducing bacterium used in this study was the strain Des. desulfuricans DSMZ 642. The strain was stored at $4^{\circ} \mathrm{C}$ in the culture medium and transferred monthly to maintain viability.

Pure cultures of Des. desulfuricans were grown in $50 \mathrm{ml}$ culture medium in $100 \mathrm{ml}$ serum bottles with continuous shaking at $26^{\circ} \mathrm{C}$.

The culture growth medium was a modified Postgate's $\mathrm{C}$ medium, with the following composition: $2 \cdot 2 \mathrm{~g} \mathrm{l}^{-1}$ $\mathrm{NH}_{4} \mathrm{Cl}, 0.008 \mathrm{~g} \mathrm{l}^{-1} \mathrm{CaCl}_{2} \cdot 2 \mathrm{H}_{2} \mathrm{O}, 0.06 \mathrm{~g} \mathrm{l}^{-1} \mathrm{MgSO}_{4} \cdot 7 \mathrm{H}_{2} \mathrm{O}$, $0.007 \mathrm{~g} \mathrm{l}^{-1} \mathrm{FeSO}_{4} \cdot 7 \mathrm{H}_{2} \mathrm{O}, 0.25 \mathrm{~g} \mathrm{l}^{-1}$ yeast extract, trace elements (B, Co, Cu, $\mathrm{Mn}$ and $\mathrm{Zn}$ ) $0.05 \mathrm{mg} \mathrm{l}^{-1}$ (each), $0.02 \mathrm{~g} \mathrm{l}^{-1} \quad \mathrm{Na}_{2}$ EDTA $2 \mathrm{H}_{2} \mathrm{O}, \quad 0.2 \mathrm{~g} \mathrm{l}^{-1} \quad \mathrm{KH}_{2} \mathrm{PO}_{4} \quad$ and $0 \cdot 44 \mathrm{~g} \mathrm{l}^{-1} \quad \mathrm{Na}_{2} \mathrm{HPO}_{4} \cdot 12 \mathrm{H}_{2} \mathrm{O}$. Sodium lactate (50\%) was used as an organic substrate with a concentration of approx. $25 \mathrm{~g} \mathrm{l}^{-1}$ and $15 \cdot 2 \mathrm{~g} \mathrm{l}^{-1} \mathrm{~K}_{2} \mathrm{SO}_{4}$ was used as a sulfate source. $430 \mathrm{mg} \mathrm{l}^{-1}$ of $\mathrm{Na}_{2} \mathrm{~S} \cdot 9 \mathrm{H}_{2} \mathrm{O}$ was used as a medium reductant and $1 \mathrm{ml} \mathrm{l}^{-1}$ of $1 \mathrm{~g} \mathrm{l}^{-1}$ of resazurin was added as a redox indicator. After adjusting the $\mathrm{pH}$ to 7 , the medium was purged with high-purity nitrogen for approx. $15 \mathrm{~min}$ and then autoclaved at $120^{\circ} \mathrm{C}$ for $20 \mathrm{~min}$.

\section{Flow cell reactor and bacterial inoculation}

The SRB biofilm was formed under turbulent flow (Reynolds number $=7000$ ) in a PMMA flow cell system within a recirculation loop to provide sufficient mixing. Turbulent flow conditions were chosen, as they are usually encountered in industrial and drinking water pipes. In the applied hydrodynamic regime, the flow cell 
behaved as a well-stirred reactor (Pereira et al. 2002). The main dimensions of the flow cell were as follows: equivalent diameter $=9.8 \mathrm{~mm}$, wet surface area $=260 \mathrm{~cm}^{2}$ and working volume of the system $=440 \mathrm{ml}$. The average water velocity in the flow cell was approx. $0.75 \mathrm{~m} \mathrm{~s}^{-1}$. Eleven independently removable coupons located in the flow cell allowed for biofilm sampling at desired time intervals. The coupons used in these assays were either SS 304 or PMMA with a surface area of $1.50 \mathrm{~cm}^{2}$. The nominal composition of the stainless steel was $\mathrm{C}, 0.05 \%$; $\mathrm{Cr}$, $17 \%$; Ni, $8 \cdot 1 \%$; Mn, $1.34 \%$; Si, 0.36\%; Cu, 0.19\%; Mo, $0 \cdot 18 \%$; Co, $0 \cdot 13 \%$ and $\mathrm{V}, 0 \cdot 09 \%$, with the balance being Fe. The coupons were degreased with detergent, rinsed with distilled water and then immersed in ethanol before being placed in the flow cell. A polishing step, usually performed in these kinds of studies, was not included in this work in order to simulate surface conditions of the material that is commonly placed in service without this treatment.

The flow cell was disinfected before use by passing a solution of sodium hypochlorite through it and rinsed with sterilized tap water. A 3-day culture of Des. desulfuricans DSMZ 642 was used to inoculate the reactor that was first operated in batch mode for 3 days and then switched to a continuous flow mode at a dilution rate (volumetric flow rate divided by working volume) of $0.5 \mathrm{~h}^{-1}$. The sterilized modified Postgate's C medium contained mineral salts with $2.5 \mathrm{~g} \mathrm{l}^{-1}$ sodium lactate (50\%), $\quad 1.5 \mathrm{~g} \mathrm{l}^{-1} \quad \mathrm{~K}_{2} \mathrm{SO}_{4}, \quad 0 \cdot 2 \mathrm{~g} \mathrm{l}^{-1} \mathrm{NH}_{4} \mathrm{Cl}, \quad 0.008 \mathrm{~g} \mathrm{l}^{-1}$ $\mathrm{CaCl}_{2} \cdot 2 \mathrm{H}_{2} \mathrm{O}, 0.06 \mathrm{~g} \mathrm{l}^{-1} \quad \mathrm{MgSO}_{4} \cdot 7 \mathrm{H}_{2} \mathrm{O}, 0.007 \mathrm{~g} \mathrm{l}^{-1} \mathrm{FeS}-$ $\mathrm{O}_{4} \cdot 7 \mathrm{H}_{2} \mathrm{O}, 0 \cdot 25 \mathrm{~g} \mathrm{l}^{-1}$ yeast extract, $0.022 \mathrm{~g} \mathrm{l}^{-1} \mathrm{Na}_{2} \mathrm{ED}$ TA. $2 \mathrm{H}_{2} \mathrm{O}, 0.02 \mathrm{~g} \mathrm{l}^{-1} \mathrm{KH}_{2} \mathrm{PO}_{4}, 0.04 \mathrm{~g} \mathrm{l}^{-1} \mathrm{Na}_{2} \mathrm{HPO}_{4} \cdot 12 \mathrm{H}_{2} \mathrm{O}$ and trace elements $(\mathrm{B}, \mathrm{Co}, \mathrm{Cu}, \mathrm{Mn}$ and $\mathrm{Zn}) 0.05 \mathrm{mg} \mathrm{l}^{-1}$ (each). The temperature in the flow cell was $26 \pm 1^{\circ} \mathrm{C}$, the $\mathrm{pH}$ was around 7 and the outlet oxygen concentration was approx. $0 \mathrm{mg} \mathrm{l}^{-1}$.

Three separately performed experiments were carried out to study biofilm formation on stainless steel surfaces and two on PMMA surfaces.

\section{Coupon sampling}

Periodically, coupons coated with biofilm were removed from the reactor. The biofilm was scraped in sterile phosphate buffer $\left(1.9 \mathrm{~g} \mathrm{l}^{-1} \mathrm{KH}_{2} \mathrm{PO}_{4}\right.$ and $4.3 \mathrm{~g} \mathrm{l}^{-1} \mathrm{Na}_{2} \mathrm{HPO}_{4}$. $12 \mathrm{H}_{2} \mathrm{O}$ ), vortexed to disperse the cells and treated for total bacteria and SRB counting. Total bacteria counts in the biofilm were determined using the 4,6 diamidino-2phenylindole (DAPI, Sigma-Aldrich, St Louis, MO, USA) staining technique and SRB were estimated by the most probable number $(\mathrm{MPN})$ method. The total bacteria and MPN counts were converted into surface area densities (number of cells per $\mathrm{cm}^{2}$ ).

\section{Total bacteria counts}

Total bacteria density was determined by DAPI staining, using the conventional epifluorescence microscopy. The phosphate buffer containing the biofilm cells was subjected to appropriate dilutions that were filtered through a blackened polycarbonate membrane $(0 \cdot 22-\mu \mathrm{m}$ pore size GTBP, 25 mm diameter; Millipore, Billerica, MA, USA) mounted on a glass filtration assembly. The membrane filter was then stained with $400 \mu \mathrm{l}$ of $0 \cdot 1 \mathrm{~g} \mathrm{l}^{-1}$ of DAPI for at least $5 \mathrm{~min}$. Distilled water was then sterile-filtered through a $0 \cdot 20-\mu \mathrm{m}$ membrane in order to remove the excess of colourant and the membrane was fixed onto a glass microscope slide. A drop of immersion oil was applied on its surface and a coverslip was laid on the top before examination with an epifluorescence microscope (Zeiss Axioskop, Carl Zeiss, Oberkochen, Germany). Cells were enumerated at $1000 \times$ magnification and bacterial density values were based on counts from 15 to 20 fields.

\section{Most probable number counts}

SRB were enumerated by the three-tube MPN method. The semisolid Postgate's B medium was prepared aerobically according to the method described by Jain (1995). The MPN tubes were initially incubated with $100 \mu \mathrm{l}$ of Pseudomonas fluorescens suspension at $30^{\circ} \mathrm{C}$ overnight. This nonSRB strain was introduced into the tube in order to create the reducing conditions appropriate for SRB growth.

Serial dilutions of the biofilm suspension were prepared in the aerobic phosphate buffer and $1 \mathrm{ml}$ of each was inoculated in the preinoculated semisolid tubes at $30^{\circ} \mathrm{C}$ for at least 7 days. At least six series of dilutions were carried out for SRB biofilm enumeration. Tubes exhibiting black precipitates anywhere in the medium were considered positive for SRB. Dubious tubes were confirmed by adding $0.5 \mathrm{ml}$ of ferric chloride solution $\left(27 \mathrm{~g} \mathrm{l}^{-1} \mathrm{FeCl}_{3}\right.$. $\left.6 \mathrm{H}_{2} \mathrm{O}\right)$ and $0.5 \mathrm{ml}$ of $p$-aminodimethylaniline dihydrochloride solution ( $2 \mathrm{~g} \mathrm{l}^{-1} \mathrm{C}_{8} \mathrm{H}_{12} \mathrm{~N}_{2} \cdot 2 \mathrm{HCl}$; Sigma-Aldrich) to the bottom of MPN tube with a syringe. A positive reaction was detected by the development of a blue colour within $10 \mathrm{~min}$ (procedure D 4412-84, ASTM 2002).

\section{Substrate removal and product production rates}

The substrate (lactate and sulfate) and product (acetate) concentrations, both in the influent and in the effluent streams, were determined by filtering the suspensions through a $0 \cdot 45-\mu \mathrm{m}$ membrane. Lactate and acetate concentrations were analysed by high performance liquid chromatography with a refractive detector (RI detector K2300; Knauer, Berlin, Germany) and a column for acid detection (PL Hi-Plex H Fast, $100 \times 7 \cdot 7 \mathrm{~cm}$; Polymer Laboratories, Shropshire, UK) and sulfate was measured by Waters capillary electrophoresis (Milford, MA, USA). 
The substrate removal and product formation rates were calculated as follows:

$$
R=\frac{D V_{\mathrm{R}}\left(S_{\mathrm{e}}-S_{\mathrm{S}}\right)}{A}
$$

where $R$ is the substrate removal (or product formation) rate $\left(\mathrm{M} . \mathrm{T}^{-1} \cdot \mathrm{L}^{-2}\right), D$ the dilution rate $\left(\mathrm{T}^{-1}\right), V_{\mathrm{R}}$ the reactor volume $\left(\mathrm{L}^{3}\right), S_{\mathrm{e}}$ the influent substrate concentration (or product concentration) (M.L $\left.{ }^{-3}\right), S_{\mathrm{s}}$ the effluent substrate concentration (or product concentration) (M.L $\mathrm{L}^{-3}$ ) and $A$ the reactor wetted surface area $\left(\mathrm{L}^{2}\right)$.

\section{Energy dispersive analysis by X-ray}

Coupons of SS 304 were analysed by energy dispersive $\mathrm{X}$-ray analysis/scanning electron microscopy (EDX/ SEM, Oxford Instruments - Link EXL II, Witney, UK) to verify the bulk elemental composition of the steel coupons in sulfur using the ZAF calculation method. Steel coupons that had been colonized by SRB and scraped off to remove the biofilm were also subjected to the same procedure.

\section{Activity tests}

Steady-state biofilm developed on PMMA and SS 304 surfaces were scraped off and dispersed in phosphate buffer as described previously. Bacterial suspensions were injected into serum bottles containing the modified Postgate's $\mathrm{C}$ medium with the following differences from the one previously described: $6.9 \mathrm{~g} \mathrm{l}^{-1}$ sodium lactate (50\%), $\quad 4.2 \mathrm{~g} \mathrm{l}^{-1} \quad \mathrm{~K}_{2} \mathrm{SO}_{4}, \quad 0.61 \mathrm{~g} \mathrm{l}^{-1} \quad \mathrm{NH}_{4} \mathrm{Cl}, \quad 0.05 \mathrm{~g}^{-1}$ $\mathrm{KH}_{2} \mathrm{PO}_{4}, 0 \cdot 12 \mathrm{~g} \mathrm{l}^{-1} \mathrm{Na}_{2} \mathrm{HPO}_{4} \cdot 12 \mathrm{H}_{2} \mathrm{O}$ and incubated with continuous shaking at $26^{\circ} \mathrm{C}$. Growth was followed by optical density at $620 \mathrm{~nm}$. Samples were also withdrawn in order to determine lactate and acetate concentrations over time.

The average doubling time was determined for bacteria developed on stainless steel and on PMMA surfaces, for each activity assay.

The activity tests were carried out twice. In the first assay, only one coupon of each substratum was used. In the second assay, two coupons of PMMA and one of SS 304 were used as sources of biofilm for the activity test.

\section{Effect of the alloying elements, $\mathrm{Cr}$ and $\mathrm{Ni}$, and $\mathrm{Fe}$ on bacterial growth}

In order to evaluate the influence of the most relevant alloying elements on Des. desulfuricans growth, nickel and chromium were added to the standard culture medium as $\mathrm{NiCl}_{2} \cdot 6 \mathrm{H}_{2} \mathrm{O}$ and $\mathrm{CrCl}_{3} \cdot 6 \mathrm{H}_{2} \mathrm{O}$. Nickel and chromium were tested at the following concentrations: $0 \cdot 10,0 \cdot 85,8 \cdot 52$ and $85 \cdot 2 \mu \mathrm{mol} \mathrm{l}^{-1}$. The control contained no metal. In the case of nickel, all tested concentrations were assayed at least in triplicate. To evaluate the influence of chromium on SRB suspensions, two assays were carried out for each concentration.

The culture medium was prepared as described above with the following differences in composition: $12.6 \mathrm{~g} \mathrm{l}^{-1}$ sodium lactate $(50 \%), 7 \cdot 8 \mathrm{~g} \mathrm{l}^{-1} \mathrm{~K}_{2} \mathrm{SO}_{4}, 1 \cdot 1 \mathrm{~g} \mathrm{l}^{-1} \mathrm{NH}_{4} \mathrm{Cl}$, $0 \cdot 10 \mathrm{~g} \mathrm{l}^{-1} \mathrm{KH}_{2} \mathrm{PO}_{4}, 0 \cdot 22 \mathrm{~g} \mathrm{l}^{-1} \mathrm{Na}_{2} \mathrm{HPO}_{4} \cdot 12 \mathrm{H}_{2} \mathrm{O}$.

Three- to four-day-old cultures were used as sources of bacterial inocula. After inoculation, the cultures were incubated with continuous rotation $\left(150 \mathrm{rev} \mathrm{min}^{-1}\right)$ at $26^{\circ} \mathrm{C}$ and growth was followed by optical density at $620 \mathrm{~nm}$.

Additionally, average doubling times $\left(t_{d}\right)$ were determined for bacterial suspensions developed with the different nickel and chromium concentrations.

Before performing the experiments with different nickel and chromium concentrations, a preliminary assay was carried out to evaluate the impact of several alloying metal ions on Des. desulfuricans growth, namely, chromium, nickel and a mixture of chromium and nickel $(\mathrm{Cr}+\mathrm{Ni})$. Considering the high iron requirements of $\mathrm{SRB}$ and in order to evaluate whether this metallic element was limiting for the bacteria, an increased iron concentration (added as $\mathrm{FeSO}_{4} \cdot 7 \mathrm{H}_{2} \mathrm{O}, 53 \cdot 72 \mu \mathrm{mol} \mathrm{l}^{-1} \mathrm{Fe}$ ) was added to the culture medium.

\section{Statistical analysis}

In order to determine the standard deviation of the total bacteria per coupon surface area, lactate and sulfate removal and acetate production rates, theorems concerning the distribution of sum, product and quotient of variables were applied (Duncan 1974).

To evaluate differences between means with a confidence level of 95\%, one-way analysis of variance (ANOvA), the nonparametric Kruskall-Wallis test and Student's $t$-test were carried out using the spss software (version 11; SPSS Inc., Chicago, IL, USA). The null hypothesis test states that the means are equal. A significance value $\leq 0.05$ indicates that there is a significant difference between the tested means. Before applying the previous procedures, it was checked whether the population from which the samples were taken presented a normal distribution and whether the samples were obtained from populations of equal variances (Levene's test of homogeneity).

ANOva testing ascertains whether or not the groups differ, but it does not specify where the significant difference is located. In order to find out which groups were significantly different to one another, post hoc comparison (Bonferroni test) was applied. 


\section{Results}

Steady-state biofilm on stainless steel and polymethylmethacrylate surfaces

SRB biofilm was developed on SS 304 and on PMMA coupons under turbulent conditions in a flow cell reactor. The assays were carried out during 25-44 days and steady-state biofilm was attained after 13-20 days of operation. Steady state was considered to be achieved when the total bacterial counts and MPN values in the biofilm per unit surface area were constant with time. Furthermore, the consumption of lactate and sulfate as well as the production of acetate were also stable with time.

No statistical difference in total bacteria counts in biofilms developed on stainless steel and on PMMA surfaces was detected at steady state (ANOva test, $P=0.455>$ $0 \cdot 05$; SS 304 assay $1-6.4 \times 10^{8} \pm 2.5 \times 10^{8}$, SS 304 assay $2-5 \cdot 9 \times 10^{8} \pm 5 \cdot 3 \times 10^{7}$, SS 304 assay $3-9 \cdot 1 \times 10^{8} \pm 1 \cdot 1 \times$ $10^{8}$; PMMA assay $1-5 \cdot 8 \times 10^{8} \pm 6 \cdot 3 \times 10^{7}$, PMMA assay $\left.2-9 \cdot 6 \times 10^{8} \pm 1.5 \times 10^{8}\right)$.

Table 1 summarizes the MPN counts obtained in steady-state biofilms developed on the two surfaces.

Considering the total bacteria and MPN values (Table 1) in the biofilm, MPN counts obtained in the biofilms developed on stainless steel coupons in assays 1 and 3 were considerably higher than the total bacteria counts. This result suggests an overestimation in SRB quantification in those biofilms. However, it should be noted that total bacteria and MPN counts were measured with completely different methods that do not allow further comparison.

Additionally, MPN results were not clear enough to allow further conclusions on the differences between SRB colonization of stainless steel and PMMA surfaces.

\section{Lactate and sulfate removal and acetate production}

In addition to biofilm measurements, the lactate, sulfate and acetate concentrations in the influent and effluent streams were quantified, which allowed the calculation of the corresponding substrate removal and product formation rates at steady state (Fig. 1).

Results show that the removal of lactate and sulfate and the production of acetate were much higher in the

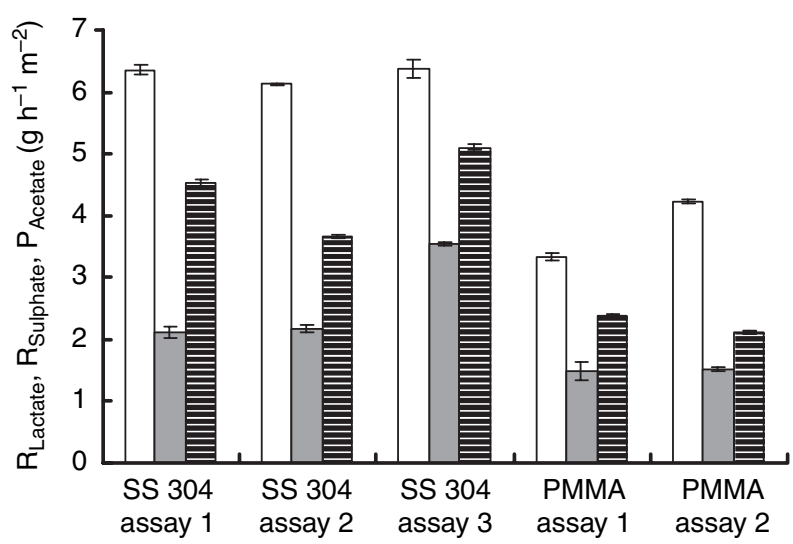

Figure 1 Lactate $\left(R_{\text {lactate }}\right)$ and sulfate $\left(R_{\text {sulfate }}\right)$ removal and acetate $\left(P_{\text {acetate }}\right)$ production rates at steady state. Data show standard deviations from three and two separate assays for stainless steel and polymethylmethacrylate, respectively. In order to determine the standard deviation, theorems concerning the distribution of sum, product and quotient of variables were applied (Duncan 1974). ( $\square$ ) $R_{\text {lactate, }}$ ( $\square) R_{\text {sulfate, }}\left(\right.$ 三) $P_{\text {acetate. }}$

assays with stainless steel as biofilm substratum than with PMMA.

\section{Activity tests}

Growth of sulfate-reducing bacteria removed from the biofilms

The growth curves of suspended bacteria scraped off from the stainless steel and PMMA coupons are presented in Fig. 2.

The growth curves obtained for suspended bacteria from biofilms developed on stainless steel and PMMA coupons were significantly different. The profiles revealed a longer lag phase of growth for the bacteria from the biofilm formed on PMMA surfaces compared with SS 304, which started almost immediately to grow.

It is interesting to notice that similar values of absorbance were attained at stationary phase for both bacterial cultures.

The values of the doubling time for the bacteria from SS 304 and PMMA biofilms were calculated from the growth curves presented in Fig. 2. The average values of the doubling time obtained for bacteria from stainless steel biofilm ( $t_{\mathrm{dSS}} 304=13.43 \pm 0.078 \mathrm{~h}$ ) was statistically

Table 1 MPN values in biofilms developed on SS 304 and PMMA surfaces at steady state

\begin{tabular}{lllll}
\hline & SS 304 assay 1 & SS 304 assay 2 & SS 304 assay 3 & PMMA assay 1 \\
\hline NMP per $\mathrm{cm}^{2}\left(\times 10^{8}\right)$ & $25 \cdot 2 \pm 3.48$ & $2 \cdot 43 \pm 1 \cdot 32$ & $22 \cdot 9 \pm 8 \cdot 90$ & $0.56 \pm 0.14$ \\
\hline
\end{tabular}

Values are reported as averages \pm SD ( $n$ between 3 and 6$)$. 


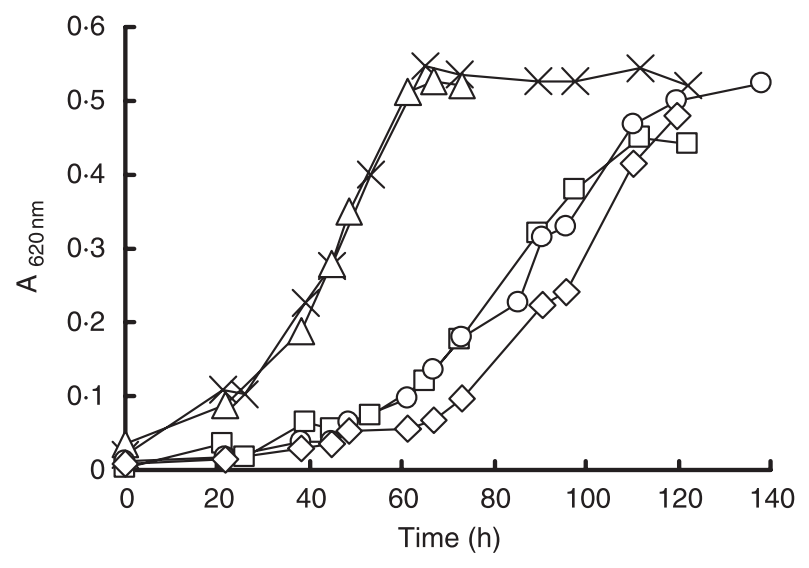

Figure 2 Growth of suspended bacteria from steady-state biofilm developed on stainless steel 304 (SS 304) and polymethylmethacrylate (PMMA) surfaces. Each value corresponds to one measurement. Two assays were performed (assay 1 and assay 2). (x) SS 304 assay 1, ( $\triangle$ ) SS 304 assay 2, ( $\square$ ) PMMA assay 1, (O) PMMA coupon 1 assay 2, $(\diamond)$ PMMA coupon 2 assay 2.

lower than that from PMMA $\left(t_{\text {dPMMA }}=17.59 \pm 1.24 \mathrm{~h}\right)$ biofilm ( $t$-test, $P=0.021<0.05)$.

Lactate and acetate concentrations during bacterial growth. Figure 3 shows the concentration of lactate and acetate over time during the growth of bacteria in biofilms formed on stainless steel and PMMA surfaces in the second activity assay. Similar trends were also obtained in the first activity test.

The consumption of lactate and production of acetate were significantly faster in the presence of bacteria grown

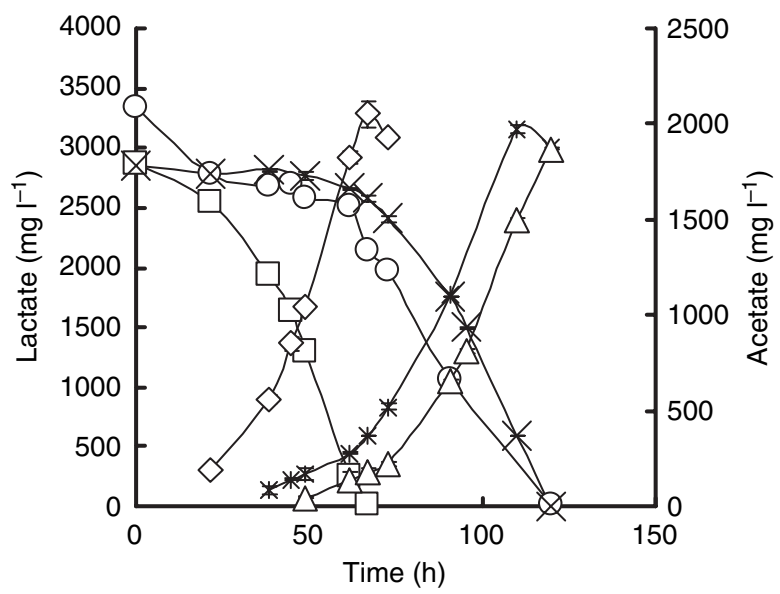

Figure 3 Lactate (Lact) and acetate (Acet) concentrations over time during sulfate-reducing bacteria growth in the activity test assay 2 . Standard deviations were obtained from three measurements. Error bars were in most cases smaller than the size of the symbol. ( $\square$ ) SS 304 Lact, ( $\diamond)$ SS 304 Acet, ( $)$ PMMA coupon 1 Lact, ( () PMMA coupon 1 Acet, $(x)$ PMMA coupon 2 Lact, $(\triangle)$ PMMA coupon 2 Acet. in biofilms formed on stainless steel coupons than with bacteria from the PMMA biofilm. These results were in good agreement with the data shown in Fig. 2.

\section{Energy dispersive analysis by X-ray}

The abundance of sulfur as a percentage of all detected elements in stainless steel surfaces that were colonized for 23 and 34 days by SRB was $0.32 \pm 0 \cdot 12 \%$ and $0 \cdot 20 \pm 0 \cdot 050 \%$, respectively. No sulfur was detected on as-received stainless steel surfaces or SS 304 colonized for 10 days. Therefore, it appears that sulfide produced by SRB biofilm was detectable on stainless steel surfaces after at least 23 days of reactor operation.

\section{Effect of the alloying elements, $\mathrm{Cr}$ and $\mathrm{Ni}$, and $\mathrm{Fe}$ on bacterial growth}

Figure 4 presents the results of a representative assay of suspended SRB growth under the effect of several nickel concentrations. It appears that nickel had a positive impact on bacterial growth, when compared with the control, especially for nickel concentrations up to $8.52 \mu \mathrm{mol} \mathrm{l}^{-1}$. The values of doubling time of the Des. desulfuricans suspensions were significantly lower when compared with the control when nickel was added to the culture medium in the following concentrations 0.85 , 8.52 and $85.20 \mu \mathrm{mol} \mathrm{l}^{-1}\left(t_{\mathrm{d} 0.85}=15.07 \pm 3.33 \mathrm{~h}, t_{\mathrm{d} 8.52}=\right.$ $17.69 \pm 1.40 \mathrm{~h}, t_{\mathrm{d} 85.20}=15.27 \pm 0.68 \mathrm{~h}, t_{\mathrm{dcontrol}}=30.24 \pm$ $4.63 \mathrm{~h}$; ANova test, $P=0<0.05$ and Bonferroni test, $P<0 \cdot 05)$.

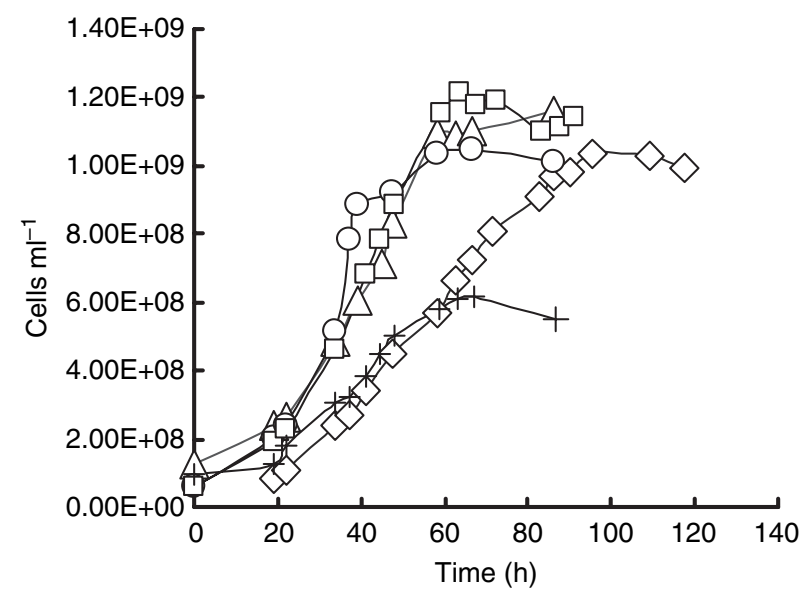

Figure 4 Influence of nickel concentration on Desulfovibrio desulfuricans suspended growth for a representative assay (at least three assays were performed for each nickel concentration and the control). Each value corresponds to one measurement. $(\diamond)$ Control, $(\triangle)$ $0.10 \mu \mathrm{mol} \mathrm{I}^{-1} \mathrm{Ni}$, (○) $0.85 \mu \mathrm{mol} \mathrm{I}{ }^{-1} \mathrm{Ni},(\square) 8.52 \mu \mathrm{mol} \mathrm{I}^{-1} \mathrm{Ni}_{\text {, }}(+)$ $85 \cdot 20 \mu \mathrm{mol} \mathrm{I}^{-1} \mathrm{Ni}$. 
In contrast, the addition of chromium to the culture medium had no significant effect on the doubling time values of the SRB within the tested concentrations and the control $\left(t_{\mathrm{d}}=21.95 \pm 0.52 \mathrm{~h}\right.$; Kruskall-Wallis test, $P=0.72>0.05)$.

A preliminary assay has been performed in order to assess the influence of the alloying elements, chromium, nickel, a mixture of chromium and nickel $(\mathrm{Cr}+\mathrm{Ni})$ on the growth of Des. desulfuricans. The influence of an increased iron concentration $(\mathrm{Fe})$ on the SRB growth was also evaluated. This assay also revealed that the Des. desulfuricans grew faster when nickel or the mixture of chromium and nickel was added to the culture medium than when chromium alone was present. Bacterial growth was very similar with nickel and with the mixture of nickel and chromium. Additionally, it was not possible to detect any significant difference between the growth profile obtained with chromium alone and the control. In addition, an increase of iron concentration in the medium did not induce any detectable effect on bacterial growth. These preliminary results emphasized the interest in studying with more detail the effect of $\mathrm{Ni}$ on SRB metabolism.

\section{Discussion}

The results obtained for the biofilms developed on stainless steel and on PMMA surfaces show similar total bacteria densities at steady state on both substrata. In contrast, data were not so clear concerning the MPN counts in those biofilms (Table 1). Even the hypothesis of an overestimation of the MPN obtained in biofilms developed on stainless steel in assays 1 and 3 did not allow concluding whether SRB numbers were significantly higher or similar on stainless steel surfaces than on PMMA surfaces. Figure 1 also shows much higher sulfate and lactate consumption and acetate production rates in the assays with stainless steel as the biofilm substratum than with PMMA.

The higher values of the removal and production rates obtained when stainless steel surfaces are used for biofilm development are consistent with a higher SRB number per unit surface area in those biofilms as well as with a possible similarity on MPN counts on both surfaces. This second possibility would mean a higher specific activity of the SRB in biofilms formed on the metallic coupons. In fact, data suggest that the composition of the surface available for bacterial colonization affects biofilm development and its metabolic activity. Bacteria attached to stainless steel coupons may acquire some metallic elements present on the metallic surface, thus influencing their development/activity.

The results obtained in the activity tests (Figs 2 and 3 ) performed with bacteria from biofilms developed on the stainless steel and on the PMMA surfaces were in good agreement with the data obtained in the continuous reactor. In fact, bacteria from the biofilm formed on SS 304 grew faster and consumed/produced the substrates and products faster. SRB from the biofilm developed on SS 304 were probably in better metabolic conditions as revealed by the lower lag phase of growth compared with the ones from PMMA. In both cases, bacteria were obliged to adapt to new conditions of growth resulting from higher nutrient concentration in the batch systems compared with the flow cell system and from changing to a suspended way of living. Bacteria from the biofilm formed on PMMA seemed to suffer a higher stress, as noted by the longer lag phase of growth. These activity tests also suggested that the material surface affected bacterial metabolism.

The culture medium used in all the assays contained a source of essential oligoelements such as $\mathrm{B}, \mathrm{Co}, \mathrm{Cu}, \mathrm{Mn}$ and $\mathrm{Zn}$ as well as a high concentration of iron, which is consistent with the high requirement of these bacteria for this element. SRB are known to require relatively high levels of iron in culture media in order to compensate for iron precipitation by sulfide (Postgate 1984; Hauser and Holder 1986; Marchal et al. 2001). Additionally, metallic elements such as nickel and chromium are present in the chemical composition of stainless steel to improve corrosion resistance. Therefore, one or several of these elements may be acquired by the SRB leading to changes on their metabolism.

The presence of sulfide on the stainless steel surface after at least 23 days of operation may be correlated to a possible attack of the stainless steel surface. Sulfide produced by SRB in the biofilm may have led to an attack of the passive layer of the stainless steel, leading to a further dissolution of metallic elements that were then available to the bacteria. It should be pointed out that the EDX/ SEM scans the coupon surface, penetrating into the material well beneath the surface oxide film which has been reported to be in the order of $2-5 \mathrm{~nm}$ in thickness (Geesey et al. 1996, 2000). In the present study, the EDX/ SEM provided the elemental abundance over a sampling depth of approx. $1 \mu \mathrm{m}$, meaning that the information provided is also concerning the underlying bulk material. Therefore, the sulfide that was detected by this technique was not only in the passive layer but also in the bulk metal. This fact further confirmed the possibility of surface attack by this end product of SRB metabolism.

Chen and Clayton (1997) also showed that the passive film on SS 304 may be deteriorated by bacterially induced sulfides and by the removal of the alloying elements. These authors detected metallic nickel in the outer layers of the passive film and they proposed the following mechanisms: (1) a transfer of nickel atoms to the outer 
surface region because of the formation of a concentration gradient of this element created by bacterial removal and (2) a nonuniform interaction that resulted in the exposure of the passive film/metal substratum interface in local areas (according to this reference, nickel is localized in an enriched layer close to the metal substratum). Videla (2001) suggested that biofilm/passive layer interactions may affect the passivity through different mechanisms, such as hindering the transport of chemical species necessary for the passivation of the surface, facilitating the dissolution and removal of oxide layers and also creating aggressive microenvironments as a result of interface changes of $\mathrm{pH}$ and concentrations of anions.

Bacterial growth under the effect of different nickel concentrations (Fig. 4) showed that nickel positively affected the growth of Des. desulfuricans. Ni appeared to be a limiting element to SRB growth under the tested conditions. In fact, concentrations of nickel between $0 \cdot 85$ and $85.20 \mu \mathrm{mol} \mathrm{l}^{-1}$ markedly decreased the doubling time of Des. desulfuricans. By contrast, chromium did not seem to influence the doubling time of the bacteria within the tested concentrations.

According to the results obtained in the present study, nickel may become available to SRB because of the sulfide attack of the protective passive film of stainless steel, subsequently affecting their metabolism. It should be pointed out that increased consumption and production rates were detected after the biofilm attained the steady state (data not shown). Sulfide attack might have led to nickel dissolution that had to attain a significant concentration in the biofilm to significantly affect bacterial metabolism. On the contrary, according to the preliminary assay, the concentration of iron in the culture medium did not seem to be limiting for the growth of SRB. Therefore, the release of iron from the metallic surface was probably not the reason for the higher consumption/production rates in biofilms developed on stainless steel surfaces. In conclusion, the present study allows to hypothesize the following mechanism of interaction of bacteria/stainless steel surface: the presence of a Des. desulfuricans biofilm on stainless steel surface, in anaerobic conditions, leads to the weakening of the passive film and to the dissolution of nickel ions that have a positive influence on the SRB metabolism. It could be speculated that nickel availability, below a toxic level, positively affects the SRB and may lead to a higher or faster degradation of the stainless steel surfaces. Therefore, the suggested mechanism may have further consequences on biocorrosion of steel.

\section{Acknowledgements}

The authors acknowledge the financial support of Programme Praxis XXI (Grant Praxis XXI/BD/13462/97).
We thank Professors Juan Lema, Mar Orge, Marga, Cristina Otero from the University of Santiago de Compostela - Spain, for their assistance with the determination of sulfate concentrations with capillary electrophoresis equipment.

\section{References}

ASTM. (2002) Standard Test Method for Sulfate-Reducing Bacteria in Water and Water-Formed Deposits. D4412-84, Easton, USA.

Beech, I.B. and Gaylarde, C.C. (1999) Recent advances in the study of biocorrosion - an overview. Rev Microbiol 30, 177-190.

Beech, I.B., Zinkevich, V., Hanjangsit, L. and Gubner, R. (1998) Modification of the passive layer on AISI 316 stainless steel in the presence of Pseudomonas NCIMB 2021 biofilm. In 3rd Latin American Congress. Cancun, Mexico, 30 August - 4 September 1988. Paper No. S19-04.

Houston, TX: NACE International.

Biezma, M.V. (1999) Microstructural features and the microbiologically influenced corrosion of stainless steels. In Microbial Corrosion, European Federation of Corrosion publications, Proceedings of the 4th International EFC Workshop ed. Sequeira, C.A.C. pp. 36-146. Lisbon, Portugal: IOM Communications.

Chen, G. and Clayton, C.R. (1997) Influence of sulfate-reducing bacteria on the passivity of type 304 austenitic stainless steel. J Electrochem Soc 44, 3140-3146.

Chen, G., Ford, T.E. and Clayton, C.R. (1998) Interaction of sulfate-reducing bacteria with molybdenum dissolved from sputter-deposited molybdenum thin films and pure molybdenum powder. J Colloid Interface Sci 204, 237246.

Dinh, H.T., Kuever, J., Mußmann, M., Hassel, A.W., Stratmann, M. and Widdel, F. (2004) Iron corrosion by novel anaerobic microorganisms. Nature 427, 829-832.

Duncan, A.J. (1974) Distribution of sums and differences. In Quality Control and Industrial Statistics ed. Irwin, R.D. pp. 102-106. Illinois: Homewood.

Edyvean, R.G.J., Percival, S., Knapp, J.S., Wales, D.S., Beech, I.B. and Videla, H. (1996) Physical and chemical differences between grades AISI 304 and 316 stainless steels and their effect on bacterial fouling and corrosion. In 2 nd NACE Latin American Region Corrosion Congress. Rio de Janeiro, Brazil, September 1996. Paper No. LA 96204. Houston, TX: NACE International.

Feugeas, F., Magnin, J.P., Cornet, A. and Rameau, J.J. (1997) Corrosion influencée par les micro-organismes: influence du biofilm sur la corrosion des aciers, techniques et résultats récents. J Phys III France 7, 631-663.

Geesey, G.G., Gillis, R.J., Avci, R., Daly, D., Hamilton, M., Shope, P. and Harkin, G. (1996) The influence of surface features on bacterial colonization and subsequent substra- 
tum chemical changes of 316L stainless steel. Corrosion Sci 38, 73-95.

Geesey, G., Beech, I., Bremer, P., Webster, B.J. and Wells, D.B. (2000) Biocorrosion. In Biofilms II Process Analysis and Applications ed. Bryers, J.D. pp. 281-325. New York: Wiley-Liss.

Gibson, G.R. (1990) Physiology and ecology of the sulphatereducing bacteria. J Appl Bacteriol 69, 769-797.

Hamilton, W.A. (1999) Microbially influenced corrosion in the context of metal microbe interactions. In Microbial Corrosion, European Federation of Corrosion Publications, Proceedings of the 4th International EFC Workshop ed. Sequeira, C.A.C. pp. 1-17. Lisbon, Portugal: IOM Communications.

Hamilton, W.A. (2003) Microbially influenced corrosion as a model for the study of metal microbe interactions: a unifying electron transfer hypothesis. Biofouling 19, 65-76.

Hauser, J.Y. and Holder, G.A. (1986) Iron availability in mixed cultures of sulfate-reducing bacteria. Biotechnol Bioeng XXVIII, 101-106.

Jain, D.K. (1995) Evaluation of the semisolid Postgate's B medium for enumerating sulfate-reducing bacteria. J Microbiol Methods 22, 27-38.

Javaherdashti, R. (1999) A review of some characteristics of MIC caused by sulfate-reducing bacteria: past, present and future. Anti-Corros Methods Mater 46, 173-180.

Lee, W., Lewandowski, Z., Nielsen, P.H. and Hamilton, W.A. (1995) Role of sulfate-reducing bacteria in corrosion of mild steel: a review. Biofouling 8, 165-194.

Little, B., Wagner, P. and Mansfeld, F. (1992) An overview of microbiologically influenced corrosion. Electrochim Acta 37, 2185-2194.
Marchal, R., Chaussepied, B. and Warzywoda, M. (2001) Effect of ferrous ion availability on the growth of a corroding sulfate-reducing bacterium. Int Biodeterior Biodegradation 47, 125-131.

Odom, J.M. (1990) Industrial and environmental concerns with sulfate-reducing bacteria. ASM News 56, 473-476.

Pereira, M.O., Morin, P., Vieira, M.J. and Melo, L.F. (2002) A versatile reactor for continuous monitoring of biofilm properties in laboratory and industrial conditions. Lett Appl Microbiol 34, 22-26.

Postgate, J.R. (1984) The Sulfate-Reducing Bacteria. Cambridge: Cambridge University Press.

Rao, T.S. and Satpathy, K.K. (1999) Studies on pitting corrosion of stainless steel (SS-304) by a marine strain of sulfate reducing bacteria (Desulfovibrio vulgaris). In Microbial Corrosion, European Federation of Corrosion Publications, Proceedings of the 4th International EFC Workshop ed. Sequeira, C.A.C. pp. 79-89. Lisbon, Portugal: IOM Communications.

Uhlig, H.H. (1975a) Pasividad. In Corrosion Y Control de Corrosion ed. Urmo, S.A. pp. 69-91. Bilbao: de Ediciones.

Uhlig, H.H. (1975b) La aleacion como medio de resistencia a la corrosion: aceros inoxidables. In Corrosion Y Control de Corrosion ed. Urmo, S.A. pp. 278-316. Bilbao: de Ediciones.

Videla, H.A. (2001) Microbially induced corrosion: an updated overview. Int Biodeterior Biodegradation 48, 176-201.

Wagner, P. and Little, B. (1993) Impact of alloying on microbiologically influenced corrosion - a review. Materials Performance, September, 65-68. 